\title{
ANALISIS SIFAT MEKANIK BAJA AISI 1018 MENGGUNAKAN PREHEAT TREATMENT
}

\author{
Muamar Khaqiqi*, Sri Mulyo Bondan Respati, Imam Syafa'at \\ Jurusan Teknik Mesin, Fakultas Teknik, Universitas Wahid Hasyim \\ JL. Menoreh Tengah X/22, Semarang 51585, Semarang \\ *Email: muamarkhaqiqi32@gmail.com
}

\begin{abstract}
Abstrak
Berbagai upaya untuk mendapatkan hasil penyambungan baja dengan pengelasan telah dilakukan. Preheat treatment merupakan satu dari sekian banyak metode yang digunakan untuk menghasilkan hasil pengelasan yang mempunyai sifat mekanik yang baik. Tujuan utama penelitian ini adalah untuk mengetahui seberapa besar pengaruh preheat pada material uji terhadap sifat mekanik yaitu kekuatan tarik, kekerasan dan struktur mikro. Penelitian ini menggunakan pipa baja karbon AISI 1018 dengan diameter 2 inci yang dilakukan proses preheat dilakukan dengan variasi suhu $300^{\circ} \mathrm{C}, 350^{\circ} \mathrm{C}, 400^{\circ} \mathrm{C}, 450^{\circ} \mathrm{C}$. Hasil preheat $350^{\circ} \mathrm{C}$ dengan nilai tegangan paling tertinggi 371,57 $\mathrm{MPa}$ dan nilai hasil kekerasan rata-rata paling tertinggi preheat $500^{\circ} \mathrm{C}$. Sedangkan nilai terendah hasil uji tarik spesimen preheat $450^{\circ} \mathrm{C}$ dengan nilai tegangan sebesar 295,37 MPa dan hasil uji kekerasan paling rendah pada preheat $300^{\circ} \mathrm{C}$. Pada struktur mikro tampak fasa ferit, perlit, martensit, dan ferit batas butir, daerah HAZ dikarenakan perlakuan panas terlalu tinggi ditambah lagi pengaruh panas proses las. Pada daerah las tampak terlihat fasa ferit dan ferit batas butir terlalu mendominasi dikarenakan perubahan suhu pada proses pengelasan terlalu lama. Struktur mikro daerah logam induk tampak fasa martensit dan tampak columnar, kemungkinan besar dalam pembuatan material melalui proses rolling.
\end{abstract}

Kata kunci: Las SMAW, Preheat, kekuatan uji tarik, kekerasan, struktur mikro

\section{PENDAHULUAN}

Perkembangan pengelasan pada zaman modern sangat pesat khususnya pada bidang otomotif, kontruksi, perkapalan, maupun perindustrian yang membutuhkan las untuk penggabungan komponen. Pengelasan adalah proses penyambungan dua buah logam dengan dipanaskan menggunakan bahan tambahan yang telah melaui proses pencairan, proses pencairan bahan tambahan inilah kemudian tercampur dengan logam induk yang membentuk sambungan. Sambungan las merupakan ikatan metalurgi sambungan logam yang dilakukan dalam keadaan cair atupun semi cair (semi solid). Preheat atau pemanasan awal adalah pemanasan yang dilakukan terhadap logam induk pada temperatur yang tepat dengan pelaksanaan pengelasan, pengerjaan ini kemungkinnan besar laju pendinginan dari daerah las dapat turun, sehingga mengurangi nilai kekerasan pada daerah pengaruh panas yang ada untuk memper cepat pelepasan hidrogen yang tercampur pada daerah las (Daryanto, 2012).

Preheat atau pemanasan awal merupakan pemanasan yang dilakukan sebelum benda kerja tersebut dikerjakan lebih lanjut, semisal sebelum pengelasan, temperatur preheat antara $30^{\circ} \mathrm{C}$ sampai $400^{\circ} \mathrm{C}$ bertujuan memenuhi sifat-sifat dibutuhkan, pada proses pemanasan material suhu austenisasi ditahan dengan waktu tertentu, contoh pelunakan pada temperatur rendah, pengerasan dan penemperan (Zumrinata, 2011).

Pengaruh preheat pada struktur mikro, kekuatan tarik logam las baja austentik AISI 304 disambung dengan baja karbon A36 dengan temperatur $100^{\circ} \mathrm{C}, 200^{\circ} \mathrm{C}, 300^{\circ} \mathrm{C}$, hasil dari las dapat mempengaruhi material, sehingga preheat menurun pada logam induk disertai peningkatan keuletan las (Saifudin dan Ilman, 2013).

Pengaruh variasi arus pengelsan SMAW elektroda E7016 pada pipa baja karbon dilas dengan vaeriasi arus 100,110,120A, diketahui hasil ketangguhan tertinggi arus 120A, dikarenakan perlakuan panas yang tinggi, maka laju pendinginan setelah pengelasan menjadi lambat (Mizhar dan Pandiangan, 2014)

Preheat dan post welding heat treatment pada proses pengelasan baja menyebabkan perubahan sifat mekanik mengalami perubahan adanya retakan daerah las, tegangan sisa dengan adanya perlakuan PWHT memberikan hasil lebih baik dalam meningkatkan sifat mekanik sambungan las (Hestiawan dan Suryono, 2014).

Penelitian ini bertujuan mengetahui pengaruh preheat pada pipa baja karbon dengan temperatur $300^{\circ} \mathrm{C}, 350^{\circ} \mathrm{C}, 400^{\circ} \mathrm{C}, 450^{\circ} \mathrm{C}, 500^{\circ} \mathrm{C}$. Untuk mengetahui perubahan struktur material 
dalam kekuatan tarik, kekerasan dan struktur mikro.

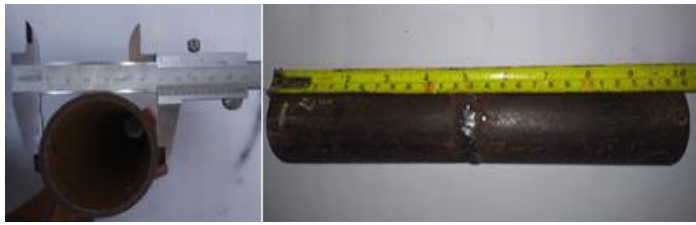

Gambar 2. Pipa baja karbon AISI 1018

Dalam penelitian ini dilakukan beberapa tahapan, pertama adalah proses preheat menggunakan gas LPG dan oksigen guna untuk memanaskan spesimen dalam keadaan stabil, selanjutnya tahap pengelasan dalam pengelasan ini kami menggunakan elektroda E7016 dengan kecepatan las, arus dianggap konstan.

Tahapan kedua adalah proses pembuatan spesimen uji tarik pada spesimen yang telah di las. Standar spesimen yang digunakan dalam pengujian tarik menggunakan standar ASME IX sesuai yang di tunjukkan pada Gambar 3 .
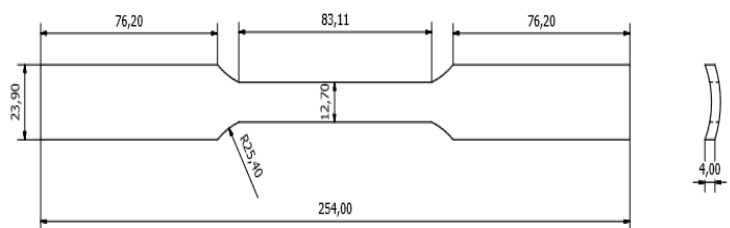

\section{Gambar 3. Spesimen uji tarik standar ASME IX}

Pada pengujian tarik ini yang bertujuan mengetahui kekuatan tarik dari material yang telah melalui proses preheat dan proses las. Tahap selanjutnya dilakukan pengujian struktur mikro bertujuan untuk mengetahui kondisi permukaan daerah las dan sekitarnya, pada proses ini sebelumnya berawal dari mempersiapkan material yang dicatak menggunakan resin terlebih dahulu, kemudian dilakukan penghalusan menggunakan amplas yang berbeda jenis kekasaran amplasnya dari amplas yang paling kasar sampai amplas yang paling halus guna untuk menghaluskan permukaan spesimen, tahap selanjutnya adalah proses peng-etsaan menggunakan larutan kimia yaitu 2\% HNO3 + 98\% dalam proses ini dilakukan guna untuk mengetahui hasil dari permukaan material saat pengujian struktur mikro. Penelitian selnjutnya adalah uji kekerasan guna untuk mengetahui kekuatan material pada daerah daerah las, HAZ dan daerah logam induk pada spesimen yang telah melalui tahap preheat.

\section{HASIL DAN PEMBAHASAN}

Hasil dari pengujian tarik dari variasi temperatur yang berbeda dapat dilihat pada Gambar 4. Grafik kekuatan tarik.

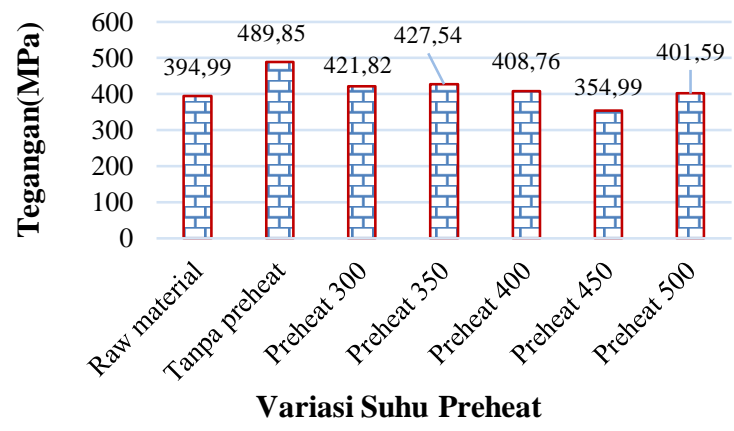

\section{Gambar 4. Grafik kekuatan tarik}

Pada Gambar 4, dapat diketahui hasil kekuatan tarik yang paling tinggi pada spesimen tanpa preheat dengan nilai $489,85 \mathrm{MPa}$, nilai paling rendah adalah preheat $450^{\circ} \mathrm{C}$ sebesar $354,99 \mathrm{MPa}$, terjadinya penurunan pada material preheat $450^{\circ} \mathrm{C}$ dikarenakan kandungan materialnya mengalami perubahan yang menyebabkan penurunan pada kekuatan tarik, semakin bertambahnya temperatur preheat maka material akan mengalami penurunan yang menyebabkan material menjadi getas,

Hasil uji kekerasan dengan variasi temperatur preheat yang berbeda, seperti pada Gambar 5. Grafik uji kekerasan.

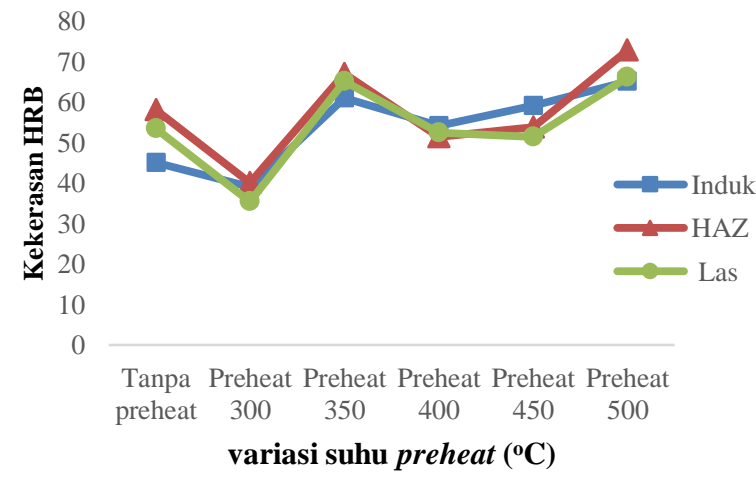

Gambar 5. Grafik uji kekerasan

Dari Gambar 5, grafik dari hasil uji kekerasan nilai paling tinggi adalah spesimen preheat $500^{\circ} \mathrm{C}$ dari semua daerah las, induk dan daerah HAZ. Untuk nilai paling rendah uji kekerasan pada spesimen preheat $300^{\circ} \mathrm{C}$ yang dikarenakan material preheat $300^{\circ} \mathrm{C}$ dalam 
kandungan material tersebut belum mengalami perubahan yang signifikan dari proses preheat.

\section{Hasil Struktur mikro.}

Hasil struktur mikro pada daerah HAZ dapat ditunjukkan Gambar 6.
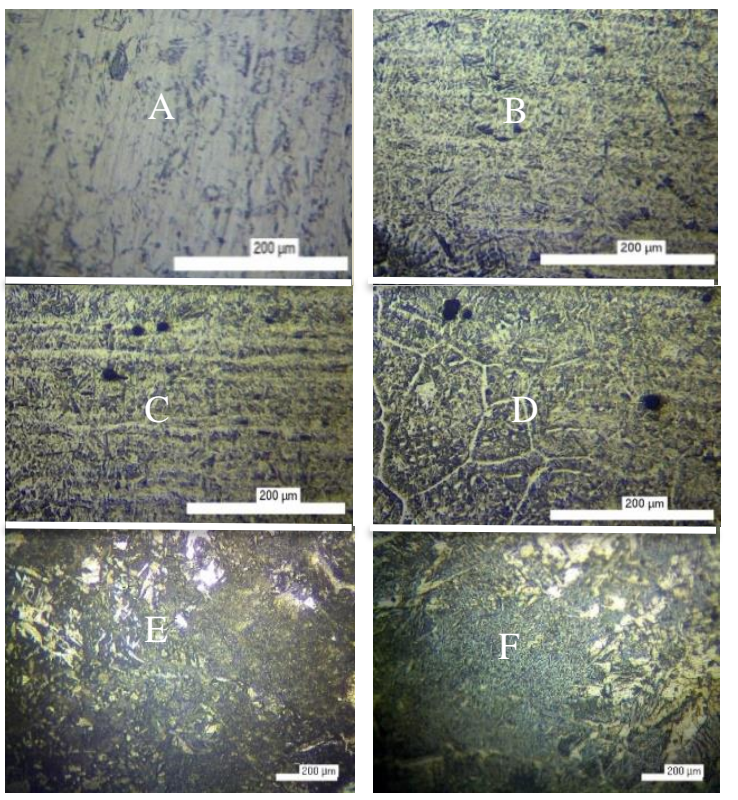

Gambar 6. Foto struktur mikro daerah HAZ
(A) Tanpa preheat
(B) Preheat $300^{\circ} \mathrm{C}$
(C) Preheat $350^{\circ} \mathrm{C}$
(D) Preheat $400^{\circ} \mathrm{C}$
(E) Preheat $5_{00}^{\circ} \mathrm{C}$
(F) Preheat $5_{00}^{\circ} \mathrm{C}$

Gambar (A) terlihat bahwa hasil pengujian struktur mikro pada daerah HAZ spesimen tanpa preheat tampak ferit yang berwarna putih cenderung lunak dan perlit berwarna gelap, tampak martensit berbentuk jarum-jarum hitam karena dalam perlakuan panas. Gambar (B) terdapat fasa martensit, fasa ferit lebih mendominasi berwarna putih, dan ada ferit widmanstatten yang berwarna putih lembut karena perubahan suhu yang lambat. (C) tampak ferit widmantatten berwarna putih dan adanya kotoran atau debu yang menempel sehingga menyebabkan terjadinya porositas. (D) terlihat bahwa ferit batas butir yang mendominasi, tampak porositas dikarenakan material mengandung korosi atau kotoran yang terjebak (E) terdapat ferit widmantatten dan ferit batas butir (F) tampak fasa ferit, perlit, martensit dan ferit widmantatten karena adanya proses perlakuan panas awal (preheat) dan terkena kembali oleh panas las sehingga material berubah menjadi getas. Hasil dari foto struktur mikro pada daerah las dapat dilihat Gambar 7.
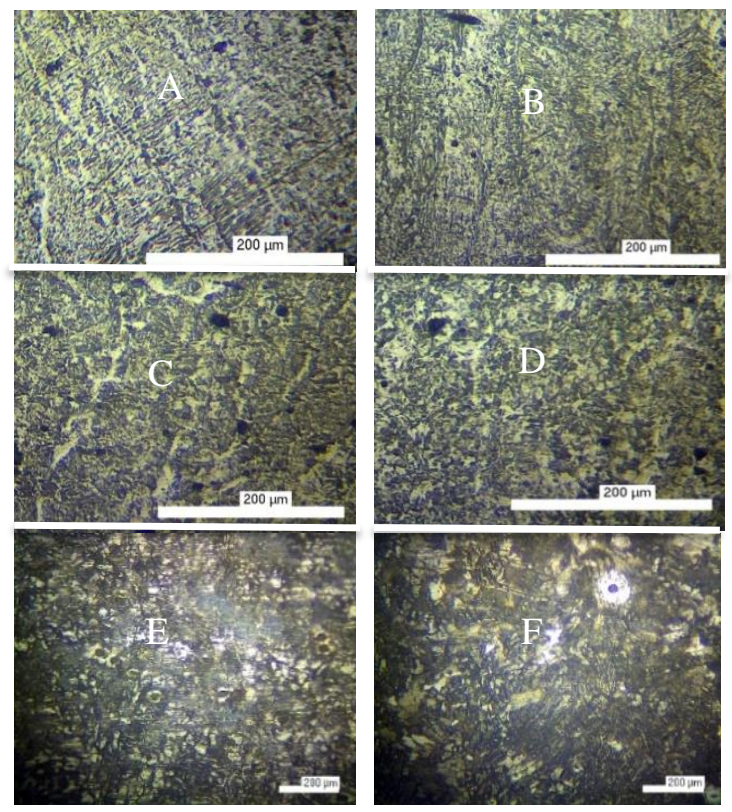

Gambar 7. Foto mikro daerah las

(A) las tanpa preheat

(B) Preheat 300oC

(C) Preheat 350oC

(D) Preheat 400oC

(E) Preheat 450oC

(F) Preheat $5_{00}^{\circ} \mathrm{C}$

Gambar 7, pada hasil uji mikro pada (A) dijelaskan spesimen las tanpa preheat tampak ferit batas butir dikarenakan perubahan suhu lambat, tampak fasa ferit yang berwarna putih (B) pada gambar B tampak ferit mendominasi sehingga mempengaruhi unsur-unsur, ferit batas butir dan martensit adapun fasa batas butir yang terlihat jelas pada gambar B. (C) tampak martensit berbentuk seperti jarum-jarum berwarna hitam dan ferit batas butir, mungkin karena pengaruh suhu preheat yang lebih tinggi, tampak fasa perlit dan sedikit ferit widmantatten. (D) fasa ferit lebih banyak dan tampak ferit batas butir, untuk fasa ferit batas butir lebih mirip dengan bentuk pelat bergaris yang dikarenakan perubahan suhu yang signifikan pada saat proses preheat dan di tambah lagi panas las oleh las. (E) fasa ferit lebih banyak dan besar yang dikarenakan mengalami perubahan suhu pada saat proses pengelasan dan tampak porositas yang di sebabkan karena adanya kotoran-kotoran yang terjebak pada material. (F) fasa ferit terlalu banyak dan struktur martensit, dan tampak sedikit porositas yang dikarenakan adanya debu 
atau kotoran-kotoran yang terjebak pada spesimen sehingga menimbulkan porositas.

Hasil foto struktur mikro daerah induk ditunjukkan pada Gambar 8 .
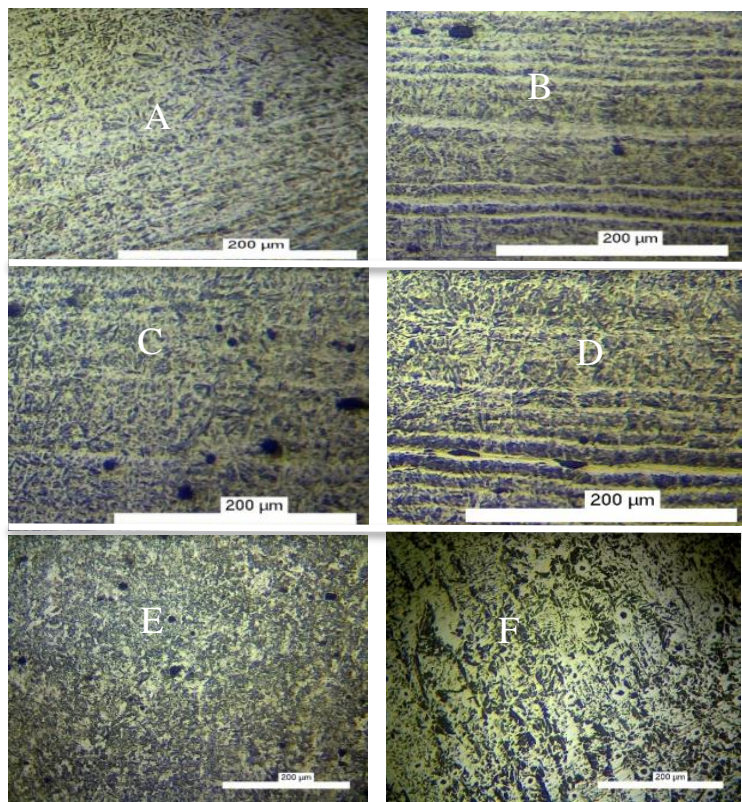

Gambar 8. Foto mikro daerah logam induk
(A) induk tanpa preheat
(B) Preheat $300^{\circ} \mathrm{C}$
(C) Preheat $350^{\circ} \mathrm{C}$
(D) Preheat $400^{\circ} \mathrm{C}$
(E) Preheat $450^{\circ} \mathrm{C}$
(F) Preheat $500^{\circ} \mathrm{C}$

Dari Gambar 8 (A) terlihat bahwa hasil pengujian struktur mikro daerah induk tampak fasa ferit dan martensit yang paling mendominasi, sedangkan perlit, ferit banyak dan rapat sehingga dapat mempengaruhi kekuatan material. (B) tampak terlihat fasa martensit yang berbentuk seperti jarum-jarum yang berwarna kehitaman. (C) fasa martensit, perlit lebih mendominasi karena adanya perubahan suhu yang terlalu lambat sehingga menimbulkan fasa perlit (D) tampak fasa perlit, martensit dan columnar yang berwarna putih memanjang kemungkinan besar disebabkan pada saat proses pembuatan material dilakukan proses rolling sehingga tampak adanya columnar (E) tampak struktur martensit dan fasa ferit widmantatten yang ditunjukkan berwarna putih lembut, sehingga kandungan oksigen terlalu banyak menyebabkan ferit widmantatten $(\mathrm{F})$ tampak ferit terlalu mendominasi disebabkan adanya perubahan suhu yang signifikan sehingga menyebabkan terjadinya tampak fasa ferit, adapun tampak porositas terjadinya porositas adalah terjebaknya kotoran-kotoran atau debu pada material sehingga menyebabkan terjadinya porositas.

\section{PENUTUP \\ Kesimpulan}

Dari penelitian dan analisa data maka dapat di ambil kesimpulan sebagai berikut:

Pengaruh preheat kekuatan tarik tertinggi spesimen tanpa preheat dengan nilai 407.69 $\mathrm{MPa}$, nilai yang terendah spesimen preheat $450^{\circ} \mathrm{C}$ sebesar $354.99 \mathrm{MPa}$, terjadinya penurunan kekuatan tarik hilangnya unsur-unsur Mn dan Si berfungsi meningkatkan kemampuan material untuk dilakukan perlakuan panas. Butirbutir fasa ferit, bainit tumbuh menjadi kasar dan besar merupakan faktor penyebab baja menjadi lebih getas. Pada hasil uji kekerasan nilai tertinggi pada daerah HAZ spesimen preheat $500^{\circ} \mathrm{C}$ nilai $72.2 \mathrm{HRB}$. Sedangkan nilai terendah $\mathrm{HAZ}$ preheat $300^{\circ} \mathrm{C}$ sebesar $40 \mathrm{HRB}$. Nilai tertinggi uji kekerasan daerah las preheat $500^{\circ} \mathrm{C}$ nilai $66 \mathrm{HRB}$, nilai terendah daerah las preheat $300^{\circ} \mathrm{C} 35,3 \mathrm{HRB}$. Uji kekerasan daerah induk tertinggi preheat $500^{\circ} \mathrm{C}$ nilai rata-rata $65 \mathrm{HRB}$, uji kekerasan induk terendah preheat $300^{\circ} \mathrm{C}$ nilai sebesar 39 HRB.

Pengaruh preheat struktur mikro pengelasan daerah logam induk preheat $300^{\circ} \mathrm{C}$ tampak fasa perlit, martensit lebih rapat dibandingkan preheat $350^{\circ} \mathrm{C}$ dan $400^{\circ} \mathrm{C}$, daerah $\mathrm{HAZ}$ pengaruh preheat $300^{\circ} \mathrm{C}$ terlihat struktur martensit, ferit widmantatten dibandingkan temperatur preheat lainya, daerah las tampak ferit batas butir dan columnar grains, struktur mikro las tanpa preheat dibandingkan pengaruh preheat daerah las lainya.

\section{DAFTAR PUSTAKA}

ASME SECTION IX (QW-462.1). 1998.

Daryanto., 2010. Proses pengolahan besi dan baja (ilmu metalurgi), cetakan 1 satu nusa, sarana tutorial nurani sejahtera, Bandung.

Hestiawan dan Suyono., 2014, Pengaruh preheat dan post welding heat treatment terhadap sifat mekanik sambungan las SMAW pada baja amutit K-340, Jurnal Mekanik, Vol, 5 No.1 Jurnal program studi Teknik Mesin, Fakultas Teknik Universitas Bengkulu.

Mizhar, S., dan Pandiangan I.H., 2014. Pengaruh masukan panas terhadap struktur mikro, kekerasan dan ketangguhan pada pengelasan shield metal 
Saifudin dan Ilman, M.N., 2013. Pengaruh preheat terhadap struktur mikro dan kekuatan tarik las logam tak sejenis baja tahan karat austenitic AISI 304 dan baja karbon A36, Jurnal Teknik Mesin Industri. Universitas Gajah Mada. Yogyakarta.

Zumrinata, 2011, Effect of Preheating Temperature, Termuat di: http://Zumrinata.wordpress.com/2011/0 3/22/ Effect of Preheating Temperaturl, diakses 27 juni 2018. 